\title{
Species-specific plant-soil feedbacks alter herbivore-induced gene expression and defense chemistry in Plantago lanceolata
}

\author{
Feng Zhu ${ }^{1} \cdot$ Robin Heinen $^{1,2} \cdot$ Martijn van der Sluijs ${ }^{1} \cdot$ Ciska Raaijmakers $^{1} \cdot$ Arjen Biere $^{1} \cdot$ T. Martijn Bezemer $^{1,2}$
}

Received: 16 February 2018 / Accepted: 18 July 2018 / Published online: 14 August 2018

(c) The Author(s) 2018

\begin{abstract}
Plants actively interact with antagonists and beneficial organisms occurring in the above- and belowground domains of terrestrial ecosystems. In the past decade, studies have focused on the role of plant-soil feedbacks (PSF) in a broad range of ecological processes. However, PSF and its legacy effects on plant defense traits, such as induction of defense-related genes and production of defensive secondary metabolites, have not received much attention. Here, we study soil legacy effects created by twelve common grassland plant species on the induction of four defense-related genes, involved in jasmonic acid signaling, related to chewing herbivore defense (LOX2, PPO7), and in salicylic acid signaling, related to pathogen defense (PR1 and PR2) in Plantago lanceolata in response to aboveground herbivory by Mamestra brassicae. We also assessed soil legacy and herbivory effects on the production of terpenoid defense compounds (the iridoid glycosides aucubin and catalpol) in P. lanceolata. Our results show that both soil legacy and herbivory influence phenotypes of $P$. lanceolata in terms of induction of $P l \mathrm{PPO} 7$ and $P l \mathrm{LOX} 2$, whereas the expression of $P l \mathrm{PR} 1$ and $P l \mathrm{PR} 2-1$ is not affected by soil legacies, nor by herbivory. We also find species-specific soil legacy effects on the production of aucubin. Moreover, P. lanceolata accumulates more catalpol when they are grown in soils conditioned by grass species. Our study highlights that PSF can influence aboveground plant-insect interactions through the impacts on plant defense traits and suggests that aboveground plant defense responses can be determined, at least partly, by plant-specific legacy effects induced by belowground organisms.
\end{abstract}

Keywords Mamestra brassicae $\cdot$ Soil legacy $\cdot$ Iridoid glycosides $\cdot$ Secondary metabolites $\cdot$ Plant defense

\section{Introduction}

As plants are members of complex communities, they simultaneously interact with both antagonists and beneficial organisms occurring both above and below the ground (Pieterse et al. 2013; Biere and Goverse 2016). To cope with challenges by harmful pathogens and insect herbivores, plants have evolved a complex immune system that modulates plant defensive responses, from recognition of alien molecules or signals from damaged plant cells to activation of effective immune responses against the attackers (Jones and Dangl 2006; Howe and Jander 2008). The phytohormones jasmonic acid (JA), salicylic acid (SA) and ethylene (ET) act as major players in coordinating the signaling pathways involved in multi-trophic species interactions among plants, microbes, and insects (Anand et al. 2008; Erb et al. 2012; Pieterse et al. 2012). In addition, beneficial relationships between plants and soil microbes are common in nature as well, improving plant growth or enhancing the plant's ability to cope with 
biotic or abiotic stress (Pineda et al. 2010; Pieterse et al. 2014). Benefits of the associations with microbes to the plants are often based on the growth-promoting effects of beneficial microbes, as well as on the activation of induced systemic resistance (ISR) resulting in sensitization of the plant immune system (priming) for a more efficient activation of plant defenses upon a future attack (Zamioudis and Pieterse 2012). Beneficial rhizosphere microbes can prime the plant for enhanced defense against a broad range of insect herbivores (Van Oosten et al. 2008; Van Wees et al. 2008; Jung et al. 2012; van de Mortel et al. 2012; Pangesti et al. 2013).

The fitness and performance of a plant can depend greatly on the conditions of the soil it grows in (Bardgett and Wardle 2010). The soil is where plants get their water and nutrients from, but it is also the center stage for interactions with a wide range of soil biota. Soil biota profoundly contribute to plant growth and productivity, and their effects range from positive to negative via respectively mutualistic or antagonistic interactions (Berendsen et al. 2012; van der Putten et al. 2013). Plants, in turn, influence the composition of the soil community around their roots via the excretion of root exudates or sheathing of dead root cells. Plant species can differ greatly in the composition and amount of these deposits, and this can lead to plant species-specific soil communities (Philippot et al. 2013; Shahzad et al. 2015). These specific soil communities can influence the performance of other plants that grow later in the same soil, a process called plant-soil feedback (PSF) (Bever 1994; van der Putten et al. 2013). PSFs can be conspecific, when the plant that grew previously in the soil affects future growth of plants of the same species, or heterospecific, when the plant species that grew previously in the soil affects future growth of other plant species. During the past decade, PSF and its legacy effects have been extensively studied in the context of plant community dynamics, such as environmental change-related range shifts, ecological succession, biological invasion and biodiversity (van der Putten et al. 2013). Recent studies revealed that induced changes in the composition of soil biota by plants could also affect aboveground multitrophic plant-insect interactions (Kostenko et al. 2012; Kos et al. 2015a; Heinen et al. 2018). Moreover, aboveground herbivory in turn can affect the outcome of PSF effects (Heinze and Joshi 2018). The functional group that a plant belongs to may also explain the way in which it influences its soil. Several studies have observed that grasses induce more positive PSF effects than forbs (van de Voorde et al. 2011; Kos et al. 2015b), and that aboveground insect herbivores perform differently on plants growing in forb-conditioned and grass-conditioned soil (Heinen et al. 2018). So far, the mechanistic understanding of how PSFs influence aboveground plant-insect interactions through affecting induced defensive responses in the plant, and how this interacts with aboveground insect herbivory on the plant, remains poorly studied.

To date, a recurring problem in insect-plant research is that most of the knowledge on defense mechanisms, especially defense gene expression, is based on model species (Heidel and Baldwin 2004; de Vos et al. 2006), or on a selected group of economically important plants such as tomato, pepper or maize (Chen et al. 2015). However, some ecologically relevant wild plant species, such as Jacobaea vulgaris, Plantago lanceolata and various species in the Brassicaceae family, have been used to study chemical defenses in response to soil biota, which has led to a better understanding of above-belowground ecology (Bezemer et al. 2006a; Soler et al. 2007; Kostenko et al. 2012; Wang et al. 2014, 2015; Kos et al. 2015a). Ribwort Plantain, $P$. lanceolata has a worldwide distribution and has been used as model species addressing plant-mediated above-belowground interactions (e.g., Gange and West 1994; Wurst et al. 2008; Bennett and Bever 2009; Wang et al. 2015). A group of plant secondary defense metabolites that has been wellcharacterized and well-studied for its ecological role in $P$. lanceolata are iridoid glycosides (IGs). In response to aboveground herbivory and soil biota, such as mycorrhizae or root herbivorous insects, the production of IGs often increases in the plant (Gange and West 1994; Wurst et al. 2008; Bennett and Bever 2009; Schweiger et al. 2014; Wang et al. 2014, 2015). These compounds act as feeding deterrents against generalist herbivores (Puttick and Bowers 1988; Biere et al. 2004; Harvey et al. 2005; Reudler et al. 2011), but can also be used as feeding and oviposition stimulants by specialist herbivores (Bowers and Puttick 1989; Nieminen et al. 2003). Previous studies have examined the effects of addition of single soil organisms on secondary defense responses, but how 'whole community' PSF processes influence plant defense has thus far not been studied in detail.

To investigate whether PSF and insect herbivory affect $P$. lanceolata defense responses, we selected four orthologs of genes that are involved in the interactions between plant and biotic agents both above- and belowground. These included a polyphenol oxidase $(P l \mathrm{PPO} 7)$, a lipoxygenase $(\mathrm{Pl} \mathrm{LOX} 2-$ $2)$, and two pathogenesis-related proteins (Pl PR1 and Pl PR2-1). Previous studies have shown that $P l$ LOX2-2 and $P l$ PPO7 are strongly induced in $P$. lanceolata after the application of JA, whereas PI PR1 and PI PR2-2 are induced by SA (Figure S1). First, Arabidopsis LOX2 is a key enzyme in the JA biosynthesis pathway induced by (generalist) chewing insect herbivores. LOX2 orthologs are commonly used as markers of JA-mediated defense responses (Chauvin et al. 2013). Second, in several plant species foliar JA-inducible PPOs play a key role in defense against a number of leaf chewing herbivores (Mayer 2006; Bosch et al. 2014). Third, the pathogenesis-related protein PR1 is often used as a marker for SA-mediated disease resistance. It is among 
the most abundantly produced proteins in plants following infection by biotrophic pathogens (Breen et al. 2017). Finally, PR2 also serves as an SA-marker. Orthologs encode a $\beta$-1,3-glucanase that has been proposed to degrade the cell walls of invading fungal pathogens. Possibly PR-proteins like PR-2 have enzymatic activities that generate elicitors of defense responses (van Loon et al. 2006).

In this study, to obtain species-specific conditioned soils, we grew twelve different co-occurring grassland plant species (including the current focal plant $P$. lanceolata) individually in live field collected soil. We then grew P. lanceolata in all twelve soils during a feedback phase and exposed a subset of these plants to aboveground herbivory by the chewing insect herbivore Mamestra brassicae (Lepidoptera: Noctuidae). We quantified the expression levels of $P$. lanceolata homologues of LOX2, PPO, PR1 and PR2. We also measured concentrations of the defense chemicals aucubin and catalpol (the two major IGs in P. lanceolata) in shoots. We address three main questions: (1) Do PSFs of the twelve plant species differ in how they influence the expression of above- and belowground defense-related genes in P. lanceolata, and does this interact with the response of the plant to aboveground herbivory? (2) Do PSFs affect chemical defense in P. lanceolata leaves? (3) Do PSFs of grasses and forbs differ in how they influence IG levels and defense gene expression in P. lanceolata and interact with aboveground herbivory?

\section{Materials and methods}

\section{Field soil}

Field soil was collected from a natural grassland site 'De Mossel' (N52 ${ }^{\circ}{ }^{\prime}, \mathrm{E}^{\circ}{ }^{\circ} 44^{\prime}$, Natuurmonumenten, Ede, The Netherlands). This field has been in use as an experimental field site since 1996 and the soil has been used in numerous plant-soil studies (e.g., Bezemer et al. 2006a, b; Heinen et al. 2018). Live soil was taken from the top $10 \mathrm{~cm}$, the well-rooted layer containing most of the rhizosphere biota. Soil was sieved to remove roots, stones and most macroinvertebrates (sieve mesh Ø1.0 cm).

\section{Plants and insects}

Ribwort Plantain (P. lanceolata) was used as a focal species. In previous studies, this species has been shown to be responsive to soil legacies and various biotic players in the soil (Bezemer et al. 2006b; Wurst et al. 2008; Wang et al. 2014, 2015), and its secondary chemistry has been well characterized (Duff et al. 1965; Bowers et al. 1992). RNA transcriptional data (RNAseq) were available for primer design from previous work at the Netherlands Institute of Ecology (A. Biere, unpublished data).

Seeds of $P$. lanceolata were surface-sterilized using 2.5\% bleach solution and then rinsed with demineralized water. For germination, seeds were placed on sterile glass beads in a climate cabinet (light regime 16:8, L:D, day temperature $21^{\circ} \mathrm{C}$, night temperature $16^{\circ} \mathrm{C}$ ). After germination, the seedlings were stored at $4{ }^{\circ} \mathrm{C}$ under the same light regime, for later use in experiments. Seeds were obtained from Cruydt-Hoeck (Nijberkoop, The Netherlands).

Eggs of the Cabbage moth, $M$. brassicae were obtained from the Department of Entomology at Wageningen University, The Netherlands. The cabbage moth had been reared for several years on Brussels Sprouts, Brassica oleracea var. gemmifera cv. Cyrus. The larvae were originally collected from cabbage fields near the university. $M$. brassicae is a generalist chewing herbivore native to the Palearctic. It is known to feed on many species of grasses and forbs, including P. lanceolata (Heinen et al. 2018).

\section{Soil conditioning phase}

Twelve common grassland plant species were chosen for soil conditioning, including six forbs: P. lanceolata (Plantaginaceae; PL), Crepis capillaris (Asteraceae; CC), Taraxacum officinale (Asteraceae; TO), Myosotis arvensis (Boraginaceae; MA), Geranium molle (Geraniaceae; GEM), and Gnaphalium sylvaticum (Asteraceae; GS); and six grasses (all Poaceae): Anthoxanthum odoratum (AO), Alopecurus pratensis (AP), Holcus lanatus (HL), Agrostis capillaris (AC), Briza media (BM), and Festuca ovina (FO). Per plant species, five replicate pots were used to condition the soil. Square pots $(11 \times 11 \mathrm{~cm})$ were filled with $1050 \mathrm{~g}$ live field soil topped off with a $0.5 \mathrm{~cm}$ layer of fine white sand to prevent oviposition by fungus gnats. In each pot, one seedling was grown for 10 weeks. Plants were kept at $17 \%$ soil moisture. After 10 weeks, the plants and their roots were removed from each pot, and the conditioned soil was mixed with sterilized field soil (1:2 conditioned:sterile $\mathrm{v} / \mathrm{v})$ to reduce variation in soil nutrient availability, keeping the five replicates separate. Sterile soil was obtained by $\gamma$-irradiation ( $>25$ Kgray, Synergy Health, Ede, The Netherlands), using the live soil that was collected from the field site.

\section{Feedback phase}

New $11 \times 11 \mathrm{~cm}$ square pots were filled with $1050 \mathrm{~g}$ of the mixtures. Two pots were filled with the same soil for each of the replicates in this experiment, one was assigned to the aboveground herbivory treatment and the other one was kept without herbivory (12 conditioned soils, two treatments (herbivore/control), five independent replicates, totaling 120 pots). Each individual pot was planted with a $P$. lanceolata 
seedling and covered by shade cloth for 3 days. After the seedlings established, the shade cloth was removed. The individual plants were grown for 4 weeks.

\section{Insect treatment}

Plants from both the undamaged control and herbivory treatment were caged using a transparent plastic tube $(8 \mathrm{~cm} \varnothing$; $25 \mathrm{~cm}$ high) with a $5-\mathrm{cm}$ mesh covering the top of the cage. Plants allocated to the insect herbivory treatment received one newly hatched L1 M. brassicae caterpillar just prior to placing the cage over the plant. The insects were left to feed for 7 days, after which they were removed and the plants were harvested. The removed caterpillars were weighed, and for each plant we measured the absolute leaf area that was consumed by the caterpillar. This was assessed using a visual reference square of $25 \mathrm{~mm}^{2}(5 \times 5 \mathrm{~mm})$ and then estimating the number of times that this visual reference would fit in the total consumed area. The number of squares was multiplied by 25 to get the consumed area per plant in $\mathrm{mm}^{2}$.

\section{Sampling}

Immediately after removing the caterpillars, the plants were harvested by clipping the aboveground plant parts with sharp surgical scissors just above soil level. The scissors were cleaned between all clippings with 10\% SDS (Biorad, The Netherlands). All leaves of each plant were then folded in aluminum foil and placed in liquid nitrogen before storage in $-80{ }^{\circ} \mathrm{C}$ until subsequent sample preparations. Prior to analysis, samples were homogenized per plant in liquid nitrogen and a subsample was taken (fresh) for transcriptome analysis. A second subsample was taken and freeze-dried for use in the chemical analyses.

\section{Quantitative real-time PCR}

Total RNA was isolated and purified from finely ground and homogenized leaf material originating from individual replicate plants with the ISOLATE II RNA Plant Kit (Bioline). Subsequently cDNA was synthesized from RNA (adjusted to $1 \mu \mathrm{g} / \mu \mathrm{l})$ using SensiFAST ${ }^{\mathrm{TM}}$ cDNA Synthesis Kit (Bioline). To investigate whether PSF and insect herbivory affect $P$. lanceolata defense responses, we selected four genes that are involved in the interactions between plant and biotic agents, including a polyphenol oxidase ( $\mathrm{Pl}$ PPO7), a lipoxygenase $(P l$ LOX2-2), and two pathogenesis-related proteins ( $P l$ PR1 and $P l$ PR2-1). $P l$ LOX2-2 and $P l$ PPO7 are induced by $\mathrm{JA}$, involved in signaling of generalist chewing herbivores, whereas Pl PR1 and Pl PR2-2 are induced by SA, involved in signaling of biotrophic pathogens (Figure S1). Gene specific primers were designed using Primer3Plus (http:// www.bioinformatics.nl/primer3plus/) and were tested for specificity and efficiency before qPCR experiments. The primer sequences used in this study are listed in Table S1. Quantitative RT-PCR analysis was performed in a CFX96 Touch $^{\text {TM }}$ Real-Time PCR Detection System (Bio-Rad). Each reaction was performed in a total volume of $20 \mu \mathrm{l}$ containing $10 \mu$ l SensiFAST SYBR ${ }^{\circledR}$ No-ROX Mix (Bioline), $5 \mu 1$ cDNA and $1 \mu \mathrm{l}$ of $400 \mathrm{nM}$ forward and reverse gene specific primer pair. For each reaction, two technical replicates were carried out and average values were used in the analyses. The following PCR program, including a melting curve analysis, was used for all PCR reactions: $3 \min 95^{\circ} \mathrm{C}$, followed by 40 cycles of $5 \mathrm{~s} 95^{\circ} \mathrm{C}, 10 \mathrm{~s} 60{ }^{\circ} \mathrm{C}$, and $20 \mathrm{~s} 72{ }^{\circ} \mathrm{C}$. The normalized expression level of each gene was calculated under the assumption of $100 \%$ primer efficiency by means of the $2^{-(\Delta \mathrm{Ct})}$ method (formula 7 of Livak and Schmittgen 2001) using the housekeeping gene glyceraldehyde-3-phosphate dehydrogenase (Pl GAPDH) as a reference. The $\Delta \mathrm{Ct}$ values were also used for statistics.

\section{Iridoid glycosides}

To determine iridoid glycoside levels in P. lanceolata, plant samples were freeze-dried for 3 days under vacuum $\left(-55^{\circ} \mathrm{C}\right.$ collector temperature; Labconco Free Zone 12 L Freeze Dry System, USA), finely ground and weighed. Twenty-five $\mathrm{mg}$ of each sample was extracted overnight in $10 \mathrm{ml}$, at room temperature in 70\% methanol (LichroSolv, VWR) using a horizontal shaker, then filtered and diluted ten times with ultrapure water. The concentrations of the IGs (aucubin and catalpol, Sigma-Aldrich) were analyzed using high-performance liquid chromatography (HPLC, Bioinert 1260 Infinity, Agilent) with electro chemical detection (ECD, Decade elite ECD, Antec). For HPLC quantification, five microliters of filtered extracts and standards was analyzed at $20^{\circ} \mathrm{C}$ with a Dionex ${ }^{\mathrm{TM}}$ Guard column CarboPac PA1 $2 \times 50 \mathrm{~mm}$, Main column CarboPac PA1 $2 \times 250$ (Thermo Fisher Scientific). The isocratic mobile phase contained $100 \% 0.1 \mathrm{M} \mathrm{NaOH}$ at a flow rate of $0.25 \mathrm{ml} / \mathrm{min}$, runtime $35 \mathrm{~min}$. Retention time (RT) was 3 and 5 min for aucubin and catalpol, respectively. The standard concentration range was $0.125-2.5 \mathrm{ppm}$.

\section{Statistical analyses}

Main effects and interactions of 'soil' (12 conditioning species) and 'herbivory' (herbivory/control) on the relative expression levels $(\Delta \mathrm{Ct})$ of the four selected $P$. lanceolata genes, as well as the concentrations of IGs (aucubin and catalpol) were analyzed by means of two-way ANOVAs. Post-hoc multiple comparisons were conducted using Tukey-Kramer tests to compare the differences among means if the models were significant.

As the conditioning species consisted of grasses and forbs, we subsequently analyzed the parameters with a 
general linear mixed model with 'functional group' as fixed factor, and 'soil identity' (12 conditioning species) as random factor.

The relationship between mean insect growth and consumption per soil treatment and mean levels of catalpol, aucubin, and four defense-related genes was determined using regression analysis.

All analyses were performed in $\mathrm{R}$ Studio, $\mathrm{R}$ version 3.0.3 (R Development Core Team 2008). Mixed models were performed using the 'nlme' package (Pinheiro et al. 2017).

\section{Results}

\section{Effects on plant biomass}

We found a marginally significant effect of soil on shoot fresh biomass $\left(F_{11,96}=1.8, p=0.065\right.$, Fig. 1a). Soil significantly affected $P$. lanceolata belowground dry biomass $\left(F_{11,96}=3.1, p=0.001\right.$, Fig. 1b). This effect was driven by the strongly negative effect of $T$. officinale, $C$. capillaris and P. lanceolata soils compared to other soils. There also was an almost significant interaction between functional group of the species that conditioned the soil and herbivore treatment $\left(F_{1,106}=3.6, p=0.061\right)$. Plants grown on forb-conditioned soils tended to produce more
Fig. 1 The effects of soil conditioning by twelve common grassland species and herbivory treatments on $\mathbf{a}$ shoot and $\mathbf{b}$ root biomass of Plantago lanceolata. Grey bars represent undamaged plants and white bars represent plants exposed to herbivory (Mamestra brassicae). Error bars represent standard errors. For each treatment combination, $n=5$. Asterisks represent significant effects; $+p<0.07$, $* p<0.05,{ }^{*} p<0.01$. Soils were conditioned by either forb or grass species. PL, Plantago lanceolata; CC, Crepis capillaris; TO, Taraxacum officinale; MA, Myosotis arvensis; GEM, Geranium molle; GS, Gnaphalium sylvaticum; AO, Anthoxanthum odoratum; AP, Alopecurus pratensis; HL, Holcus lanatus; AC, Agrostis capillaris; BM,

Briza media; FO, Festuca ovina
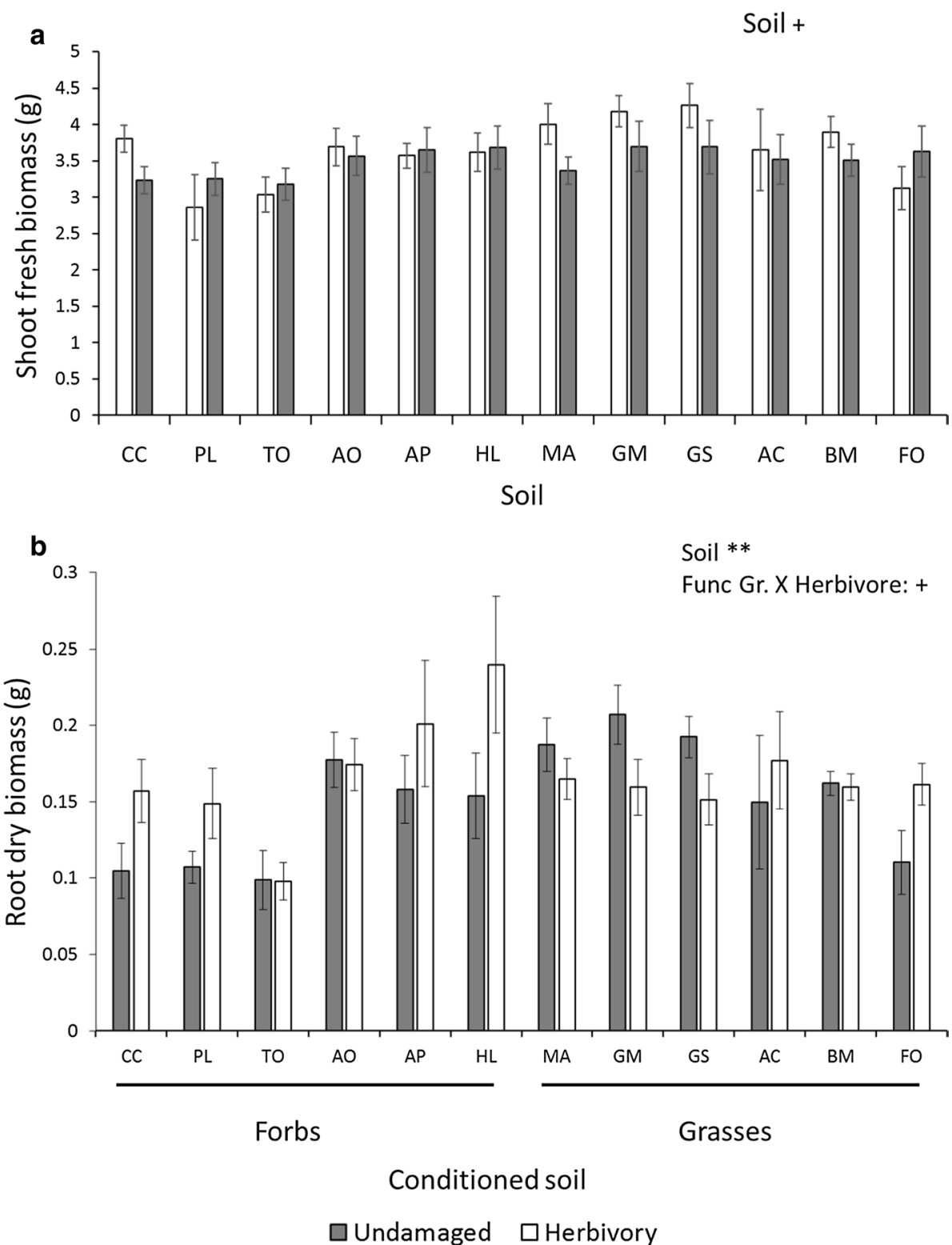
root biomass when they experienced herbivory than control plants, whereas this was not observed for plants grown on grass-conditioned soils (see Fig. 1b).

\section{Effects on defense related gene expression}

Among the four defense-related genes in P. lanceolata, the relative expression of $\mathrm{Pl} \mathrm{PPO} 7$ was significantly affected by soil conditioning species and by herbivory (Soil: $F_{11.95}=2.87 ; p=0.003$; Herbivory: $F_{1,95}=9.73$; $p=0.002) . P l$ PPO7 expression levels were higher under herbivory treatments, but the levels varied when plants were grown on different soils (Fig. 2a). The expression level was highest when $P$. lanceolata was grown on soils that were previously conditioned by G. sylvaticum and lowest on soils conditioned by $M$. arvensis, A. odoratum and A. pratensis.

A significant interactive effect of herbivory treatment and soil conditioning species was found on the expression of $P l$ LOX2-2 (Herbivory $\times$ Soil: $F_{11,96}=2.17 ; p=0.022$ ). The expression was upregulated by herbivory treatment on some soils (i.e., P. lanceolata, T. officinale, H. lanatus and F. ovina), but downregulated (as compared to caged control plants on the same soils) on soils conditioned by some of the other species (most notably A. capillaris, B. media, $C$. capillaris and G. sylvaticum, Fig. 2b).

Expression of $P l$ PR1 and $P l$ PR2-1 was not affected by herbivory treatments, although we found a marginally significant effect of soil on $P l$ PR1 expression (Soil: $F_{11,94}=1.87$; $p=0.053$, Fig. $2 \mathrm{c}$ and d, Table S2), most likely driven by the high levels found in P. lanceolata grown on soils conditioned by $C$. capillaris.

For $\mathrm{Pl}$ PPO7, the transcript levels were slightly higher in plants that had been grown in forb-conditioned soils compared to those that had been grown in grass-conditioned soils (Functional group: $F_{1,10}=4.53 ; p=0.059$ ).

\section{Effects on plant chemistry}

The plant species that conditioned the soil significantly differed in how they affected concentrations of aucubin in shoots of P. lanceolata $\left(F_{11,96}=2.40 ; p=0.011\right.$; Fig. 3a). Catalpol was not affected by soil conditioning (Table S2). Aucubin levels of plants grown in soils conditioned by $T$. officinale, were relatively low, whereas levels in soils conditioned by $C$. capillaris, $M$. arvensis and $G$. molle were two to three times higher than those in soils conditioned by $T$. officinale (Fig. 3a). Catalpol levels were significantly higher in P. lanceolata plants that were grown on grass-conditioned soils, than those that were grown on forb-conditioned soils $\left(F_{1,10}=5.76 ; p=0.037\right.$, Fig. $\left.3 b\right)$.
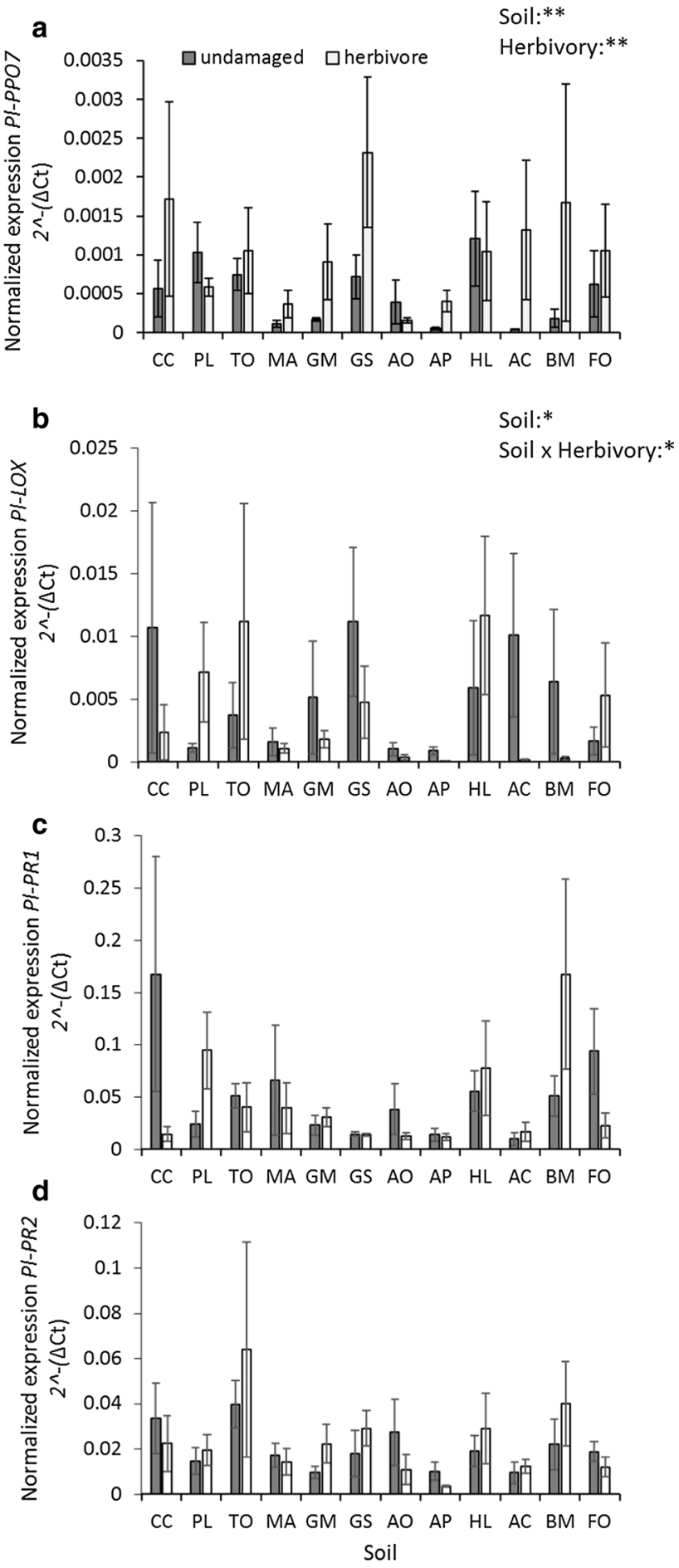

Fig. 2 The effects of soil conditioning by twelve common grassland species and herbivory treatments on the relative gene expression levels of four genes in the shoots of Plantago lanceolata: Pl PPO7 (a), Pl LOX2-2 (b), Pl PR1 (c) and $P l$ PR2-1 (d). Values represent normalized gene expression levels $\left[2^{-(\Delta \mathrm{Ct})}\right]$ relative to GAPDH. Grey bars represent undamaged and white bars represent herbivory (Mamestra brassicae) treatments. Error bars represent standard errors. For each treatment combination, $n=5$. Asterisks represent significant effects; $* p<0.05, * * p<0.01$. Soils were conditioned by either forb or grass species. PL, Plantago lanceolata; CC, Crepis capillaris; TO, Taraxacum officinale; MA, Myosotis arvensis; GEM, Geranium molle; GS, Gnaphalium sylvaticum; AO, Anthoxanthum odoratum; AP, Alopecurus pratensis; HL, Holcus lanatus; AC, Agrostis capillaris; BM, Briza media; FO, Festuca ovina 


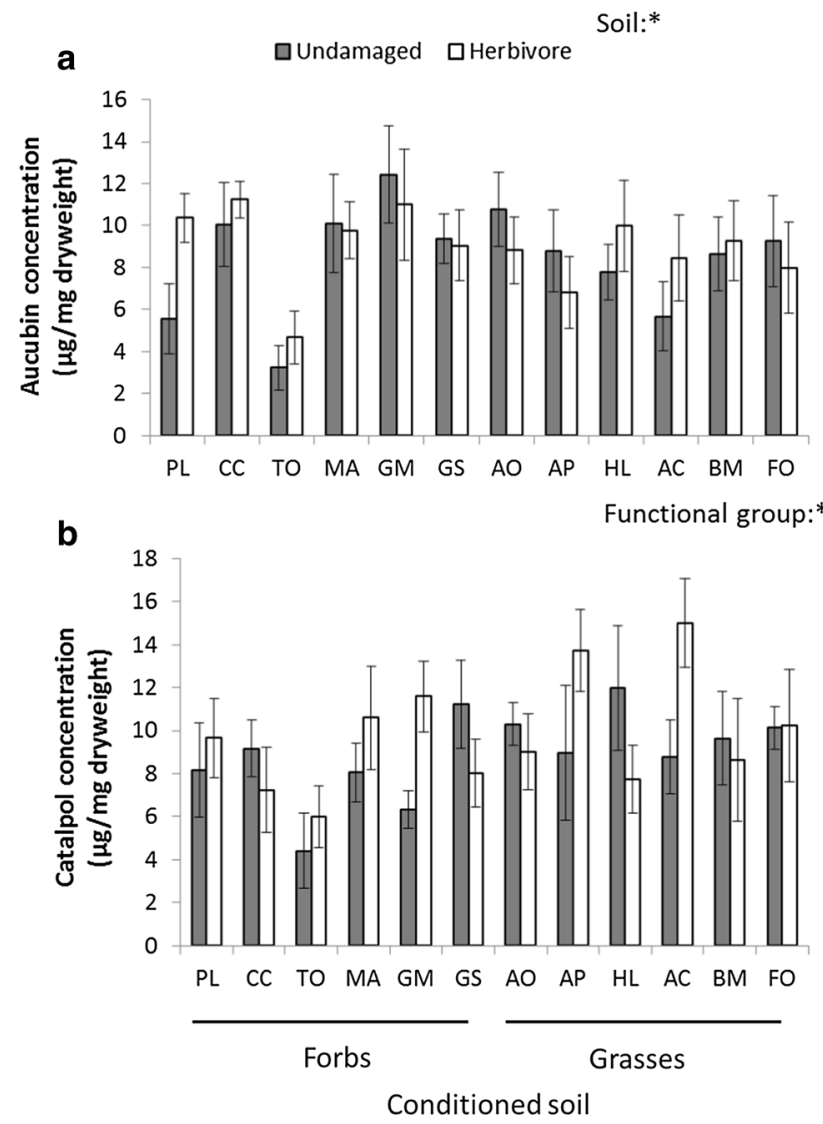

Fig. 3 The effects of soil conditioning by twelve common grassland species and herbivory treatment on levels of aucubin (a) and catalpol (b), in the shoots of Plantago lanceolata. Grey bars represent undamaged and white bars represent herbivory (Mamestra brassicae) treatments. Error bars represent standard errors. For each treatment combination, $n=5$. Asterisks represent significant effects; $* p<0.05$, $* * p<0.01$. Soils were conditioned by either forb or grass species. PL, Plantago lanceolata; CC, Crepis capillaris; TO, Taraxacum officinale; MA, Myosotis arvensis; GEM, Geranium molle; GS, Gnaphalium sylvaticum; AO, Anthoxanthum odoratum; AP, Alopecurus pratensis; HL, Holcus lanatus; AC, Agrostis capillaris; BM, Briza media; FO, Festuca ovina

\section{Effects on caterpillar performance}

Species-specific soil legacies did not influence biomass of $M$. brassicae larvae $\left(F_{11,37}=0.57, p=0.84\right.$, Figure S2a $)$, nor leaf area consumption by the caterpillars $\left(F_{11,42}=1.27\right.$; $p=0.28$, Figure $\mathrm{S} 2 \mathrm{~b}$ ).

\section{Correlations between consumption and caterpillar biomass}

Caterpillar biomass showed a marginally significant positive correlation with caterpillar consumption $\left(R^{2}=0.33\right.$, $p=0.052$, Supplementary Figure S3).

\section{Discussion}

In this study, we examined how soil legacy effects and aboveground herbivory interact to influence growth and defense responses in the perennial forb P. lanceolata. We assessed treatment effects on the transcript levels of four defense-related genes, and measured the production of two secondary defense metabolites, catalpol and aucubin. Our results show that soil conditioning by plants can influence the response of the plant in terms of defense-related gene expression and the production of secondary defense metabolites.

Ribwort plantain, when exposed to M. brassicae infestation, showed an up-regulation in transcription of the defenserelated gene $\mathrm{Pl} \mathrm{PPO} 7$ that putatively codes for a polyphenol oxidase (PPO). PPOs are known to be induced by herbivory and confer resistance to a broad range of insect herbivores (War et al. 2012). Interestingly, we found that soil conditioning by different plant species also can influence transcript levels of $P l$ PPO7. Moreover, we found an interaction between herbivory and the plant species that conditioned the soil on the overall transcript levels of $P l$ LOX2-2, a gene that is involved in the biosynthesis of JA. $P l$ LOX2-2 was up-regulated by herbivory in some of the conditioned soils, most notably in soils conditioned by $P$. lanceolata, $T$. officinale, $H$. lanatus and $F$. ovina. However, on other soils, herbivory showed no effect on transcript levels of $P l \mathrm{LOX} 2-$ 2 , or the gene had a lower expression under the herbivory treatment, compared to control plants (most notably in soils conditioned by $C$. capillaris, G. sylvaticum, A. capillaris and $B$. media). These results suggest that, at the transcription level, the JA-mediated defensive responses against chewing herbivores may depend on the soil that $P$. lanceolata is growing in. In this study plant material was sampled when the caterpillars had fed on plants for 7 days, thus we were not able to detect the induction of $P l$ LOX2-2 at early stages of herbivory. As lipoxygenase genes are generally considered to respond relatively fast to herbivore damage (Heitz et al. 1997), future studies should follow these induction patterns through a time series.

SA-regulated defense responses are often associated with piercing and sap-sucking insects and with biotrophic and hemibiotrophic phytopathogens (Anand et al. 2008; Pieterse et al. 2014). Soil pathogens are often considered to be important drivers of PSF effects (van der Putten et al. 2013). Therefore, we expected that specific PSFs would affect soil biotic conditions and thereby affect the activation of SA related genes in the plant. In our study, the transcript levels of $P l$ PR2-1, a marker related to the SA signaling pathway, was not strongly affected by the treatments although we found a marginally significant effect of soil conditioning on its homolog marker $P l$ PR1. 
Besides harmful pathogens, soils also host microbes that have beneficial relationships with the host plants (Philippot et al. 2013). These beneficial soil microbes, such as mycorrhizae and plant-growth promoting rhizobacteria, have been shown to prime the plant for effective defense responses (Pozo and Azcon-Aguilar 2007; Jung et al. 2012). Soil conditioning likely also influences the compositions of other soil organisms that may alter a plant's phenotype. Although soil biotic composition was not specifically characterized in this study, in another experiment, performed with the same plant species as we used here, and carried out under similar experimental conditions, plants greatly impacted the structure of soil microbial communities (Heinen et al. 2018).

In the current study, chewing herbivores were used as the inducer of plant defenses. Since chewing herbivores generally invoke the JA pathway rather than the SA pathway (Ali and Agrawal 2012), the absence of an effect of herbivory on the expression of SA-related genes is in line with expectations. Future studies should be conducted to find out whether SA-related gene expression would respond more strongly to soil conditioning when plants are under attack by phloemfeeding herbivores that more commonly induce the SA signaling pathway.

Seeds of Ribwort plantain were not derived from the same genetic background, and plant material used for gene expression analysis was collected from individual $P$. lanceolata replicates. The relative expression values in our study exhibit large variation, indicating strong variability among individual plants in their response to the soils. Most studies on gene expression pool samples from multiple plants, and analyze these pooled samples, which can greatly reduce the variation. We purposely did not pool samples in our study, since individual plants may not respond in the same way and this information cannot be inferred from pooled samples. It may well be that not all individual plants were induced to the same extent. This could be due to differences among individual plants in how they respond to a given set of soil microbes, but also due to differences in the composition of soil organisms among replicate soils. Certain microbes may be present or absent in replicates even though they originated from the same replicate pot with conditioned soil. Nevertheless, even without pooling, our study shows that $P$. lanceolata responded differently to combined soil legacy and herbivory effects with respect to the induction of defense-related genes.

The metabolites aucubin and catalpol have been wellstudied in P. lanceolata and several studies have shown that both compounds can be induced by herbivory, and by soil organisms (Bowers and Stamp 1993; Marak et al. 2002; Biere et al. 2004; Harvey et al. 2005), such as soil pathogens or arbuscular mycorrhizal fungi (Gange and West 1994; Schweiger et al. 2014; Wang et al. 2015). In this study, P. lanceolata secondary defense metabolites were also affected by soil conditioning by twelve different plant species. We only found an effect of soil conditioning species on aucubin levels, which seems to be mainly driven by very low levels of aucubin in P. lanceolata growing in soils conditioned by $T$. officinale. In a previous study, $T$. officinale had a negative effect on microbial biomass in the soil (Wardle and Nicholson 1996). As IG levels are often elevated when the plant interacts with microorganisms and nematodes (Wurst et al. 2010), we speculate that differences in IG levels detected may be caused, at least partially, by variation in the activity or community composition of soil organisms. Previous studies have indicated that grasses and forbs differ in their microbial profile in the soil (Kos et al. 2015b; Latz et al. 2015, 2016) and that this can affect aboveground plant-insect interactions (van de Voorde et al. 2011; Kos et al. 2015b; Heinen et al. 2018). In our study, catalpol levels were significantly higher in $P$. lanceolata on soils that were conditioned by grasses, than on those that were conditioned by forbs, regardless of the herbivore treatment. It has also been shown that IGs levels in P. lanceolata negatively correlate with nutrient levels available in the soil (Darrow and Bowers 1999; Marak et al. 2003), so a nutritional soil legacy effect cannot be ruled out. In this study, all soils were mixed with two volumes sterilized field soil, which was done to minimize the effect of soil nutritional differences in the feedback phase.

In conclusion, our results shed light on the effect of plantinduced variation in soil biotic and abiotic conditions on defense responses to aboveground herbivory in plants that grow later in these conditioned soils. Until now, mechanisms of how PSF may influence aboveground plant-insect interactions have been highly speculative. Further studies are required, but here we provide evidence that soil legacies can be important drivers of insect-plant interactions-via their influence on plant defense chemistry and the JA-pathway. We showed these effects in a relatively realistic ecological framework, using live soils and natural soil conditioning. Future studies should focus on disentangling the changes in the soil microbiome involved, and manipulating the different classes of soil organisms, such as decomposers, pathogens and beneficial organisms within this framework, to better understand what drives these changes in plant defense.

Acknowledgements The authors thank Gregor Disveld for providing greenhouse space for the experiments and Freddy ten Hooven for practical assistance during the initial phase of the experiment. The authors also thank Léon Westerd and André Gidding at the Department of Entomology at Wageningen University for providing eggs of Mamestra brassicae. The comments of two anonymous referees greatly improved the manuscript. The research was supported by the Netherlands Organization for Scientific Research, NWO VICI grant 865.14.006 to TMB. This is publication number XXXX of the NIOO-KNAW.

Author contribution statement FZ, RH and TMB conceived and designed the experiments. RH, MS, TMB and FZ performed 
transcriptome analyses. $\mathrm{CR}$ performed chemical analyses. $\mathrm{FZ}$ and $\mathrm{RH}$ analyzed the data. RH, FZ, AB and TMB wrote the manuscript. All authors approved final version for publication.

Open Access This article is distributed under the terms of the Creative Commons Attribution 4.0 International License (http://creativeco mmons.org/licenses/by/4.0/), which permits unrestricted use, distribution, and reproduction in any medium, provided you give appropriate credit to the original author(s) and the source, provide a link to the Creative Commons license, and indicate if changes were made.

\section{References}

Ali JG, Agrawal AA (2012) Specialist versus generalist insect herbivores and plant defense. Trends Plant Sci 17:293-302. https://doi. org/10.1016/j.tplants.2012.02.006

Anand A et al (2008) Salicylic acid and systemic acquired resistance play a role in attenuating crown gall disease caused by Agrobacterium tumefaciens. Plant Physiol 146:703-715. https://doi. org/10.1104/pp.107.111302

Bardgett RD, Wardle DA (2010) Aboveground-belowground linkages: biotic interactions, ecosystem processes and global change. Oxford University Press, New York

Bennett AE, Bever JD (2009) Trade-offs between arbuscular mycorrhizal fungal competitive ability and host growth promotion in Plantago lanceolata. Oecologia 160:807-816. https://doi.org/10.1007/ s00442-009-1345-6

Berendsen RL, Pieterse CMJ, Bakker P (2012) The rhizosphere microbiome and plant health. Trends Plant Sci 17:478-486. https://doi. org/10.1016/j.tplants.2012.04.001

Bever JD (1994) Feedback between plants and their soil communities in an old field community. Ecology 75:1965-1977. https://doi. org/10.2307/1941601

Bezemer TM, Harvey JA, Kowalchuk GA, Korpershoek H, van der Putten WH (2006a) Interplay between Senecio jacobaea and plant, soil, and aboveground insect community composition. Ecology 87:2002-2013. https://doi. org/10.1890/0012-9658(2006)87[2002:Ibsjap]2.0.Co;2

Bezemer TM et al (2006b) Plant species and functional group effects on abiotic and microbial soil properties and plant-soil feedback responses in two grasslands. J Ecol 94:893-904. https://doi.org/1 $0.1111 / \mathrm{j} .1365-2745.2006 .01158 . x$

Biere A, Goverse A (2016) Plant-mediated systemic interactions between pathogens, parasitic nematodes, and herbivores aboveand belowground. Annu Rev Phytopathol 54:499-527. https://doi. org/10.1146/annurev-phyto-080615-100245

Biere A, Marak HB, van Damme JMM (2004) Plant chemical defense against herbivores and pathogens: generalized defense or tradeoffs? Oecologia 140:430-441. https://doi.org/10.1007/s0044 2-004-1603-6

Bosch M, Berger S, Schaller A, Stintzi A (2014) Jasmonate-dependent induction of polyphenol oxidase activity in tomato foliage is important for defense against Spodoptera exigua but not against Manduca sexta. BMC Plant Biol 14:257. https://doi.org/10.1186/ s12870-014-0257-8

Bowers MD, Puttick GM (1989) Iridoid glycosides and insect feeding preferences: gypsy moths (Lymantria dispar, Lymantriidae) and buckeyes (Junonia coenia, Nymphalidae). Ecol Entomol 14:247256. https://doi.org/10.1111/j.1365-2311.1989.tb00953.x
Bowers MD, Stamp NE (1993) Effects of plant-age, genotype, and herbivory on Plantago performance and chemistry. Ecology 74:1778-1791. https://doi.org/10.2307/1939936

Bowers MD, Collinge SK, Gamble SE, Schmitt J (1992) Effects of genotype, habitat, and seasonal variation on iridoid glycoside content of Plantago lanceolata (Plantaginaceae) and the implications for insect herbivores. Oecologia 91:201-207. https://doi. org/10.1007/BF00317784

Breen S, Williams SJ, Outram M, Kobe B, Solomon PS (2017) Emerging insights into the functions of pathogenesis-related protein 1 . Trends Plant Sci 22:871-879. https://doi.org/10.1016/j.tplan ts.2017.06.013

Chauvin A, Caldelari D, Wolfender JL, Farmer EE (2013) Four 13-lipoxygenases contribute to rapid jasmonate synthesis in wounded Arabidopsis thaliana leaves: a role for lipoxygenase 6 in responses to long-distance wound signals. New Phytol 197:566575. https://doi.org/10.1111/nph.12029

Chen YH, Gols R, Benrey B (2015) Crop domestication and its impact on naturally selected trophic interactions. Annu Rev Entomol 60:35-58. https://doi.org/10.1146/annurev-ento-010814-020601

Darrow K, Bowers MD (1999) Effects of herbivore damage and nutrient level on induction of iridoid glycosides in Plantago lanceolata. J Chem Ecol 25:1427-1440. https://doi.org/10.1023/A:10209 91229072

De Vos M, Van Zaanen W, Koornneef A, Korzelius JP, Dicke M, Van Loon LC, Pieterse CM (2006) Herbivore-induced resistance against microbial pathogens in Arabidopsis. Plant Physiol 142:352-363. https://doi.org/10.1104/pp.106.083907

Duff RB, Bacon JSD, Mundie CM, Farmer VC, Russell JD, Forreste AR (1965) Catalpol and methylcatalpol: naturally occurring glycosides in Plantago and Buddleia species. Biochem J 96:1-5

Erb M, Meldau S, Howe GA (2012) Role of phytohormones in insectspecific plant reactions. Trends Plant Sci 17:250-259. https://doi. org/10.1016/j.tplants.2012.01.003

Gange AC, West HM (1994) Interactions between arbuscular mycorrhizal fungi and foliar-feeding insects in Plantago lanceolata L. New Phytol 128:79-87. https://doi.org/10.1111/j.1469-8137.1994. tb03989.x

Harvey JA, Van Nouhuys S, Biere A (2005) Effects of quantitative variation in allelochemicals in Plantago lanceolata on development of a generalist and a specialist herbivore and their endoparasitoids. J Chem Ecol 31:287-302. https://doi.org/10.1007/s1088 6-005-1341-1

Heidel AJ, Baldwin IT (2004) Microarray analysis of salicylic acid- and jasmonic acid-signalling in responses of Nicotiana attenuata to attack by insects from multiple feeding guilds. Plant Cell Environ 27:1362-1373. https://doi.org/10.1111/j.1365-3040.2004.01228.x

Heinen R, van der Sluijs M, Biere A, Harvey JA, Bezemer TM (2018) Plant community composition but not plant traits determine the outcome of soil legacy effects on plants and insects. J Ecol 106(3):1217-1229. https://doi.org/10.1111/1365-2745.12907

Heinze J, Joshi J (2018) Plant-soil feedback effects can be masked by aboveground herbivory under natural field conditions. Oecologia 186:235-246. https://doi.org/10.1007/s00442-017-3997-y

Heitz T, Bergey DR, Ryan CA (1997) A gene encoding a chloroplasttargeted lipoxygenase in tomato leaves is transiently induced by wounding, systemin, and methyl jasmonate. Plant Physiol 114:1085-1093. https://doi.org/10.1104/pp.114.3.1085

Howe GA, Jander G (2008) Plant immunity to insect herbivores. Annu Rev Plant Biol 59:41-66. https://doi.org/10.1146/annurev.arpla nt.59.032607.092825

Jones JDG, Dangl JL (2006) The plant immune system. Nature 444:323-329. https://doi.org/10.1038/nature05286

Jung SC, Martinez-Medina A, Lopez-Raez JA, Pozo MJ (2012) Mycorrhiza-induced resistance and priming of plant defenses. J Chem Ecol 38:651-664. https://doi.org/10.1007/s10886-012-0134-6 
Kos M, Tuijl MAB, de Roo J, Mulder PPJ, Bezemer TM (2015a) Plant-soil feedback effects on plant quality and performance of an aboveground herbivore interact with fertilisation. Oikos 124:658-667. https://doi.org/10.1111/oik.01828

Kos M, Tuijl MAB, de Roo J, Mulder PPJ, Bezemer TM (2015b) Species-specific plant-soil feedback effects on above-ground plant-insect interactions. J Ecol 103:904-914. https://doi. org/10.1111/1365-2745.12402

Kostenko O, van de Voorde TFJ, Mulder PPJ, Van der Putten WH, Bezemer TM (2012) Legacy effects of aboveground-belowground interactions. Ecol Lett 15:813-821. https://doi.org/10.1 111/j.1461-0248.2012.01801.x

Latz E, Eisenhauer N, Scheu S, Jousset A (2015) Plant identity drives the expression of biocontrol factors in a rhizosphere bacterium across a plant diversity gradient. Funct Ecol 29:1225-1234. https ://doi.org/10.1111/1365-2435.12417

Latz E, Eisenhauer N, Rall BC, Scheu S, Jousset A (2016) Unravelling linkages between plant community composition and the pathogen-suppressive potential of soils. Sci Rep 6:23584. https:// doi.org/10.1038/srep23584

Livak KJ, Schmittgen TD (2001) Analysis of relative gene expression data using real-time quantitative PCR and the $2^{-\Delta \Delta \mathrm{Ct}}$ method. Methods 25:402-408. https://doi.org/10.1006/meth.2001.1262

Marak HB, Biere A, Van Damme JMM (2002) Systemic, genotypespecific induction of two herbivore-deterrent iridoid glycosides in Plantago lanceolata L. in response to fungal infection by Diaporthe adunca (Rob.) niessel. J Chem Ecol 28:2429-2448. https ://doi.org/10.1023/A:1021475800765

Marak HB, Biere A, Van Damme JMM (2003) Fitness costs of chemical defense in Plantago lanceolata L.: effects of nutrient and competition stress. Evolution 57:2519-2530. https://doi. org/10.1111/j.0014-3820.2003.tb01496.x

Mayer AM (2006) Polyphenol oxidases in plants and fungi: going places? A review. Phytochemistry 67:2318-2331. https://doi. org/10.1016/j.phytochem.2006.08.006

Nieminen M, Suomi J, Van Nouhuys S, Sauri P, Riekkola ML (2003) Effect of iridoid glycoside content on oviposition host plant choice and parasitism in a specialist herbivore. J Chem Eco 29:823-844. https://doi.org/10.1023/A:1022923514534

Pangesti N, Pineda A, Pieterse CMJ, Dicke M, van Loon JJA (2013) Two-way plant-mediated interactions between root-associated microbes and insects: from ecology to mechanisms. Front Plant Sci 4:414. https://doi.org/10.3389/fpls.2013.00414

Philippot L, Raaijmakers JM, Lemanceau P, van der Putten WH (2013) Going back to the roots: the microbial ecology of the rhizosphere. Nat Rev Microbiol 11:789-799. https://doi.org/10.1038/nrmic ro3109

Pieterse CMJ, Van der Does D, Zamioudis C, Leon-Reyes A, Van Wees SCM (2012) Hormonal modulation of plant immunity. Annu Rev Cell Dev Bi 28:489-521. https://doi.org/10.1146/annurev-cellb io-092910-154055

Pieterse CMJ, Poelman EH, Van Wees SCM, Dicke M (2013) Induced plant responses to microbes and insects. Front Plant Sci 4:475. https://doi.org/10.3389/fpls.2013.00475

Pieterse CMJ, Zamioudis C, Berendsen RL, Weller DM, Van Wees SCM, Bakker PAHM (2014) Induced systemic resistance by beneficial microbes. Annu Rev Phytopathol 52:347-375. https://doi. org/10.1146/annurev-phyto-082712-102340

Pineda A, Zheng SJ, van Loon JJA, Pieterse CMJ, Dicke M (2010) Helping plants to deal with insects: the role of beneficial soilborne microbes. Trends Plant Sci 15:507-514. https://doi. org/10.1016/j.tplants.2010.05.007

Pinheiro J, Bates D, DebRoy S, Sarkar D, R Core Team (2017) nlme: linear and nonlinear mixed effects models. $\mathrm{R}$ package version 3.1-131, https://CRAN.R-project.org/package $=$ nlme
Pozo MJ, Azcon-Aguilar C (2007) Unraveling mycorrhiza-induced resistance. Curr Opin Plant Biol 10:393-398. https://doi. org/10.1016/j.pbi.2007.05.004

Puttick GM, Bowers MD (1988) Effect of qualitative and quantitative variation in allelochemicals on a generalist insect: iridoid glycosides and the southern armyworm. J Chem Ecol 14:335-351. https ://doi.org/10.1007/Bf01022550

Reudler JH, Biere A, Harvey JA, van Nouhuys S (2011) Differential performance of a specialist and two generalist herbivores and their parasitoids on Plantago lanceolata. J Chem Ecol 37:765-778. https://doi.org/10.1007/s10886-011-9983-7

Schweiger R, Baier MC, Persicke M, Muller C (2014) High specificity in plant leaf metabolic responses to arbuscular mycorrhiza. Nat Commun 5:3886. https://doi.org/10.1038/ncomms4886

Shahzad T, Chenu C, Genet P, Barot S, Perveen N, Mougin C, Fontaine S (2015) Contribution of exudates, arbuscular mycorrhizal fungi and litter depositions to the rhizosphere priming effect induced by grassland species. Soil Biol Biochem 80:146-155. https://doi. org/10.1016/j.soilbio.2014.09.023

Soler R, Bezemer TM, Cortesero AM, Van der Putten WH, Vet LEM, Harvey JA (2007) Impact of foliar herbivory on the development of a root-feeding insect and its parasitoid. Oecologia 152:257264. https://doi.org/10.1007/s00442-006-0649-z

R Development Core Team (2008) R: a language and environment for statistical computing. R Foundation for Statistical Computing, Vienna, Austria. ISBN 3-900051-07-0. http://www.R-project.org

Van de Mortel JE, de Vos RC, Dekkers E, Pineda A, Guillod L, Bouwmeester K, van Loon JJA, Dicke M, Raaijmakers JM (2012) Metabolic and transcriptomic changes induced in Arabidopsis by the rhizobacterium Pseudomonas fluorescens SS101. Plant Physiol 160:2173-2188. https://doi.org/10.1104/pp.112.207324

Van de Voorde TFJ, van der Putten WH, Bezemer TM (2011) Intraand interspecific plant-soil interactions, soil legacies and priority effects during old-field succession. J Ecol 99:945-953. https://doi. org/10.1111/j.1365-2745.2011.01815.x

Van der Putten WH, Bardgett RD, Bever JD, Bezemer TM, Casper BB, Fukami T, Kardol P, Klironomos JN, Kulmatiski A, Schweitzer JA, Suding KN, van de Voorde TFJ, Wardle DA (2013) Plantsoil feedbacks: the past, the present and future challenges. J Ecol 101:265-276. https://doi.org/10.1111/1365-2745.12054

Van Loon LC, Rep M, Pieterse CMJ (2006) Significance of inducible defense-related proteins in infected plants. Annu Rev Phytopathol 44:135-162. https://doi.org/10.1146/annurev.phyto.44.07050 5.143425

Van Oosten VR, Bodenhausen N, Reymond P, Van Pelt JA, Van Loon LC, Dicke M, Pieterse CM (2008) Differential effectiveness of microbially induced resistance against herbivorous insects in Arabidopsis. Mol Plant Microbe Interact 21:919-930. https://doi. org/10.1094/Mpmi-21-7-0919

Van Wees SCM, Van der Ent S, Pieterse CMJ (2008) Plant immune responses triggered by beneficial microbes. Curr Opin Plant Biol 11:443-448. https://doi.org/10.1016/j.pbi.2008.05.005

Wang MG, Biere A, Van der Putten WH, Bezemer TM (2014) Sequential effects of root and foliar herbivory on aboveground and belowground induced plant defense responses and insect performance. Oecologia 175:187-198. https://doi.org/10.1007/s0044 2-014-2885-y

Wang MG, Bezemer TM, van der Putten WH, Biere A (2015) Effects of the timing of herbivory on plant defense induction and insect performance in ribwort plantain (Plantago lanceolata $\mathrm{L}$.) depend on plant mycorrhizal status. J Chem Ecol 41:1006-1017. https:// doi.org/10.1007/s10886-015-0644-0

War AR, Paulraj MG, War MY, Ignacimuthu S (2012) Differential defensive response of groundnut germplasms to Helicoverpa 
armigera (Hubner) (Lepidoptera: Noctuidae). J Plant Interact 7:45-55. https://doi.org/10.1080/17429145.2011.587898

Wardle DA, Nicholson KS (1996) Synergistic effects of grassland plant species on soil microbial biomass and activity: implications for ecosystem-level effects of enriched plant diversity. Funct Ecol 10:410-416. https://doi.org/10.2307/2390291

Wurst S, Van Dam NM, Monroy F, Biere A, Van der Putten WH (2008) Intraspecific variation in plant defense alters effects of root herbivores on leaf chemistry and aboveground herbivore damage. J Chem Ecol 34:1360-1367. https://doi.org/10.1007/ s10886-008-9537-9

Wurst S, Wagenaar R, Biere A, van der Putten WH (2010) Microorganisms and nematodes increase levels of secondary metabolites in roots and root exudates of Plantago lanceolata. Plant Soil 329:117-126. https://doi.org/10.1007/s11104-009-0139-2

Zamioudis C, Pieterse CMJ (2012) Modulation of host immunity by beneficial microbes. Mol Plant Microbe Interact 25:139-150. https://doi.org/10.1094/mpmi-06-11-0179 